\title{
GAMBARAN KECEPATAN PEMBUSUKAN HEWAN COBA DI DAERAH PESISIR PANTAI MANADO
}

\author{
${ }^{1}$ Stephanus K. I. Pangaila \\ ${ }^{2}$ Erwin g. kristanto \\ ${ }^{2}$ Johanis F. Mallo
}

\author{
${ }^{1}$ Kandidat Skripsi Fakultas Kedokteran Universitas Sam Ratulangi Manado \\ ${ }^{2}$ Bagian Ilmu Kedokteran Forensik Fakultas Kedokteran Universitas Sam Ratulangi Manado \\ Email: stephanus.pangaila@gmail.com
}

\begin{abstract}
The duration of decay process in humans depends on climate, place, media, and the presence of other factors, such as insects. The duration of decay for areas that have a snow climate is hampered because of the low temperature, while in areas with tropical climates such as Indonesia the duration of decay will not be hampered unless the corpse is in the water earlier for a long period it will take place in the inhibition of decay. Decay caused by spoilage bacteria work mainly Closteridium welchii. This study aimed to describe the duration of decay on the coast of Manado and to explain the clinical signs were found on the corpse that had been rotted. This study was carried out in Manado from 14 December 2013 to 29 December 2013. This was a descriptive study by using primary and secondary data. A local pig was used as model. The results showed that during 15 days of observation, there were 5 stages of decomposition: 1 ) fresh stage days $0-1$; bloated stage days 2-3; active decay stage days 4-8; post-decay stage days 8-12; and skeletonization days 13-15.
\end{abstract}

Keywords: forensic medicine, the decay rate

\begin{abstract}
Abstrak: Kecepatan proses pembusukan pada manusia berbeda-beda baik dalam hal iklim, tempat, media dan adanya faktor lain. Kecepatan pembusukan untuk daerah yang beriklim dingin akan terjadi penghambatan dalam kecepatan pembusukannya sedangkan di daerah yang beriklim tropis seperti Indonesia kecepatan pembusukan tidak akan terhambat kecuali mayat yang ditemukan dalam air sebelumnya dalam jangka waktu yang cukup lama sehingga akan terjadi penghambatan dalam pembusukannya. Pembusukan disebabkan oleh pekerjaan bakteri-bakteri terutama Closteridium welchii. Penelitian ini bertujuan untuk mengetahui gambaran kecepatan pembusukan di pesisir pantai Manado dan menjelaskan tanda klinik yang didapatkan pada bangkai yang sudah membusuk. Penelitian dilakukan di Manado 14 29 Desember 2013. Penelitian ini bersifat deskriptif dengan mengunakan data primer dan sekunder, menggunakan hewan coba, hewan pemakan bangkai dan tanda-tanda pembusukan sebagai Variabel penelitian. Hasil penelitian yang dilakukan selama 15 hari maka ditemukan tahap-tahap terjadinya proses pembusukan dari fresh stage hari 0-1, bloated stage hari 2-3, active decay stage hari 4-8, post decay stage hari 8-12 dan skeletonization hari 13-15.
\end{abstract}

Kata kunci: kedokteran forensik, kecepatan pembusukan 
Kecepatan proses pembusukan pada manusia berbeda-beda baik dalam hal iklim, tempat, media dan adanya faktor lain. Kecepatan pembusukan untuk daerah yang memiliki iklim salju akan terjadi penghambatan dalam kecepatan pembusukannya karena dalam suhu yang rendah pembusukan akan terhambat sedangkan di daerah yang memiliki iklim tropis seperti Indonesia kecepatan pembusukan tidak akan terhambat kecuali mayat yang ditemukan telah berada dalam air sebelumnya dalam jangka waktu yang cukup lama sehingga akan terjadi penghambatan dalam pembusukannya.

Kecepatan pembusukan juga di pengaruhi daerah seperti adanya anjing atau serigala yang telah memakan tubuh mayat sehingga proses pembusukan menjadi lebih cepat dari biasanya. Kecepatan pembusukan juga di pengaruhi dari bakteri yang ada dalam tubuh manusia seperti bakteri basil Coliformis dan Clostridium Welchii yang menjadi kontribusi akhir organisme penghancur jaringan pada fase akhir dari pembusukan. ${ }^{1}$

Data proses pembusukan umumnya diambil dari Eropa. karena data-data di Indonesia/Manado masih sedikit, khusunya penelitian di pesisir pantai Manado/Indonesia umumnya belum ada penelitian yang dilakukan.

Manfaat pengetahuan kecepatan pembusukan ini untuk menetukan waktu kematian dari mayat yang di temukan para polisi dan para dokter.Kecepatan pembusukan di eropa yang memiliki 4 iklim mempunyai kecepatan pembusukan yang berbeda dengan Negara Indonesia yang hanya memiliki 2 iklim saja. Perbandingan kecepatan pembusukan mayat yang berada dalam tanah : air : udara adalah $1: 2: 8$. Bayi baru lahir umumnya lebih lambat membusuk, karena hanya memiliki sedikit bakteri dalam tubuhnya dan hilangnya panas tubuh yang cepat pada bayi akan menghambat pertumbuhan bakteri. ${ }^{2}$

Pembusukan jenazah terjadi akibat proses degradasi jaringan karena autolisis dan kerja bakteri. Mulai muncul 24 jam postmortem, berupa warna kehijauan dimulai dari daerah sekum menyebar ke seluruh dinding perut dan berbau busuk karena terbentuk gas seperti HCN, H2S dan lainlain. Gas yang terjadi menyebabkan pembengkakan. Akibat proses pembusukan rambut mudah dicabut, wajah membengkak, bola mata melotot, kelopak mata membengkak dan lidah terjulur. Pembusukan lebih mudah terjadi pada udara terbuka suhu lingkungan yang hangat/panas dan kelembaban tinggi. Bila penyebab kematiannya adalah penyakit infeksi maka pembusukan berlangsung lebih cepat. ${ }^{3}$

Dan juga Larva lalat akan dijumpai setelah pembentukan gas pembusukan nyata, yaitu kira-kira 36-48 jam pasca mati. Kumpulan telur lalat telah dapat ditemukan beberapa jam pasca mati, di alis mata, sudut mata, lubang hidung dan diantara bibir. ${ }^{2}$

Berdasarkan data di atas, penulis menyimpulkan bahwa pembusukan merupakan suatu masalah yang sangat penting dalam bidang kedokteran forensik. Akan tetapi belum ada penelitian tentang pembusukan di pesisir pantai kota Manado, mengingat Manado memiliki iklim yang tidak menentu. Oleh sebab itu penulis tertarik untuk meneliti tentang gambaran kecepatan pembusukan di daerah pesisir pantai Manado. Dengan menggunakan babi sebagai hewan coba. Karena babi merupakan mamalia dengan struktur anatomi dan fisiologi yang 
tidak jauh berbeda dengan manusia, sehingga seringkali di gunakan dalam penelitian perkembangan dunia medis manusia. ${ }^{4}$

\section{METODE PENELITIAN}

Penelitian yang dilakukan adalah penelitian dengan metode deskriptif dengan menggunakan data primer dan sekunder.Penelitian dilakukan pada bulan oktober 2013 desember 2013, dan tempat penelitian dilakukan di bagian Animal House Fakultas Kedokteran Sam Ratulangi Manado.Cara pembuatan penelitian ini dengan hasil penelitian, Pengolahan data dilakukan secara manual dengan menggunakan laptop dan Pengkajian data dalam bentuk tulisan dan table distribusi frekuensi.Objek penelitian dalam hal ini adalah bangkai babi yang dibiarkan membusuk di pesisir pantai Manado, dengan memakai variabel penelitian hewan coba, hewan pemakan bangkai dan tanda-tanda pembusukan. Data yang diperoleh ditabulasikan menurut variabel penelitian yaitu : hewan coba, hewan pemakan bangkai, tandatanda pembusukan.

\section{HASIL PENELITIAN}

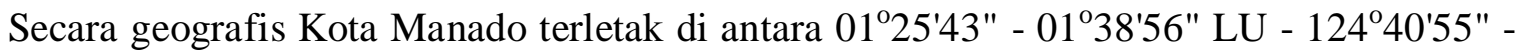
$124^{\circ} 55^{\prime} 54$ " BT, luas wilayahnya adalah 157,91 Km2 atau 1,04\% dari luas Provinsi Sulawesi Utara. Perbatasan wilayahnya ialah di sebelah timur berbatasan dengan Kecamatan Dimembe, di sebelah barat berbatasan dengan Teluk Manado, Laut Sulawesi, di sebelah utara berbatasan dengan Kecamatan Wori, Kabupaten Minahasa dan Teluk Manado, dan di sebelah selatan berbatasan dengan Kecamatan Pineleng. Wilayah ini terbagi atas 9 Kecamatan dan 87 Desa. ${ }^{5}$ Di Manado, suhu berkisar $23-31{ }^{\circ} \mathrm{C}$ dan kelembaban 68-97\%. ${ }^{6}$

\section{Tabel 1. Tahap Pembusukan Pada Babi}

\begin{tabular}{cc}
\hline Tahap pembusukan & Hari \\
\hline Fresh stage & $\mathbf{0 - 1}$ \\
Bloated stage & $2-3$ \\
Active decay stage & $\mathbf{4 - 8}$ \\
Post decay stage & $\mathbf{8 - 1 2}$ \\
skeletonization & $\mathbf{6 - 1 5}$ \\
\hline
\end{tabular}


Dari Tabel 1 tahap pembusukan dapat dilihat bahwa fresh stage itu terjadi pada hari ke 0-1, bloated stage hari ke 2-3 hari, active decay stage hari ke 4-8, post decay stage hari ke 8-12, dan skeletonization hari ke 13-15. Suhu ruangan: $29-30^{\circ} \mathrm{C}$ dan Kelembaban ruangan 71-79\%.

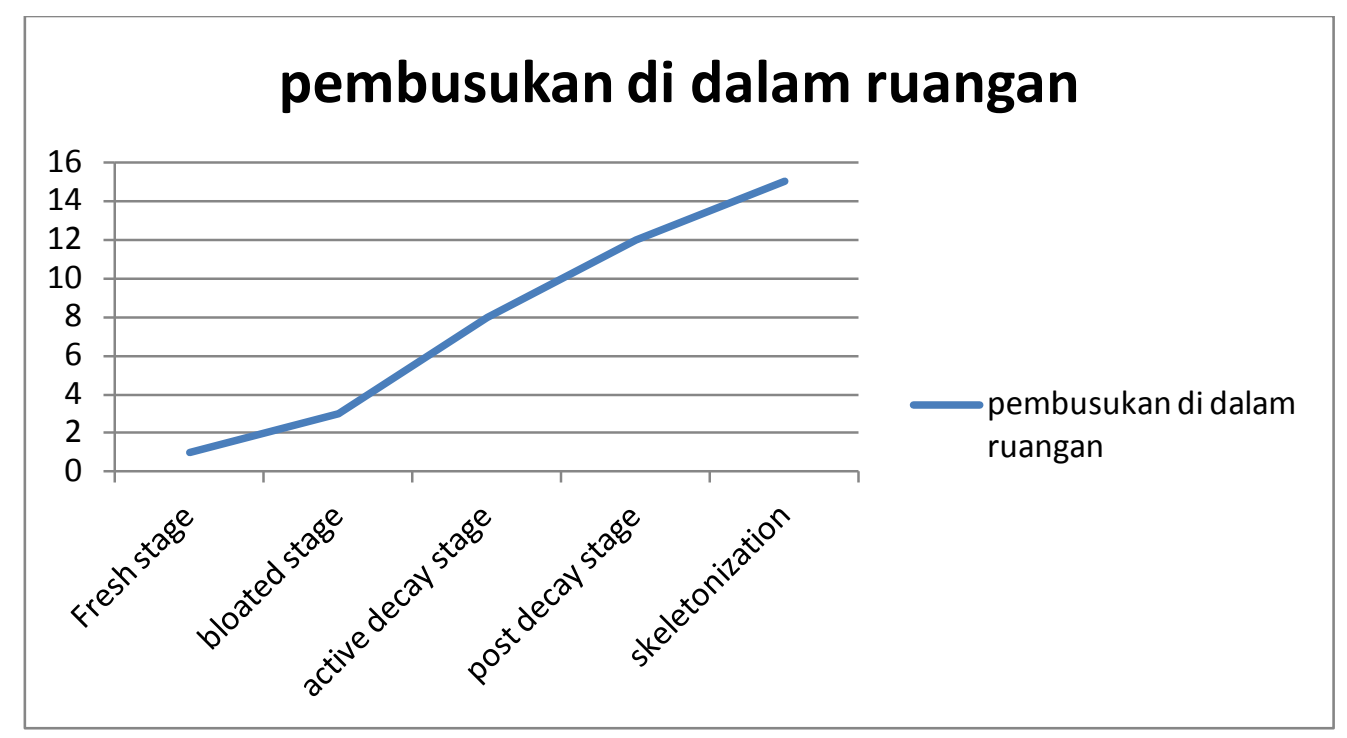

Gambar 1. Tahap-tahap terjadinya pembusukan

\section{BAHASAN}

Kecepatan pembusukan di daerah pesisir pantai manado yang tepatnya diletakan di dalam ruangan yang dilakukan selama 15 hari mendapatkan hasil, dimana bagian kepala dan kaki babi paling cepat terjadi skeletonization dari pada bagian tubuh yang lain, karena kepala babi mengeluarkan darah yang banyak ketika di hantam dengan kayu sedangkan kaki babi kecil dan tipis sehingga cepat terjadi proses skeletonization.

Pada tahap fresh stage terjadi rigor mortis, algor mortis dan lalat mulai menghinggapi hewan coba. Bloated stage terjadi pada hari ke 2 sampai 3 dengan mulai terjadinya pembengkakan perut, protusio ani, dan wajah mulai rusak.

Active decay stage terjadi selama hari ke 4-8 dimana kulit sudah mulai pecah, wajah sudah rusak dimakan larva, usus sudah terburai. Post decay stage terjadi pada hari ke 8-12 dimana wajah, kaki, dan dada sudah dimakan larva, usus dan isi perut lainnya sudah dimakan larva. Pada proses skeletonization sudah mulai terjadi dari hari 13-15 dimana kepala pertama kali terjadi skeletonization setelah itu kaki dan anggota tubuh lainnya.

Proses pembusukan di negeri 2 musim dengan memakai babi sebagai hewan coba lebih cepat terjadi pembusukan karena pembusukan terjadi karena ada faktor dari cuaca dan hewan pengerat disekitar lokasi penelitian, untuk negeri 2 musim ini faktor cuaca yang hanya ada musim panas dan hujan membuat proses pembusukan lebih cepat dari pada proses pembusukan di negeri 4 musim yang memakai babi sebagai hewan coba yang memiliki musim panas, hujan, salju dan gugur. 
Hewan pengerat juga yang berada di sekitar tempat terjadi pembusukan seperti di luar ruangan anjing, kucing, musang, burung, lalat, semut, tikus dan kumbang dapat mempercepat terjadi proses pembusukan.

Sedangkan di dalam ruangan yang memakai babi sebagai hewan coba proses pembusukan lebih lambat sedikit daripada di luar ruangan yang memakai babi sebagai hewan coba karena hewan pengerat di dalam ruangan hanya sedikit tidak seperti yang berada di luar ruangan contohnya tikut, semut, kumbang, lalat, larva dan hewan kecil lainnya yang membantu terjadinya pembusukan.

Larva lalat dapat kita temukan pada mayat kira-kira 36-48 jam pasca kematian.Berguna untuk memperkirakan saat kematian dan penyebab kematian karena keracunan. Saat kematian dapat kita perkirakan dengan cara mengukur panjang larva lalat. Penyebab kematian karena racun dapat kita ketahui dengan cara mengidentifikasi racun dalam larva lalat.Pada grafik 3 akan memperlihatkan bagaimana perbedaan kecepatan pembusukan diluar ruangan dan di dalam ruangan dalam Negara 2 musim seperti Indonesia yang memakai babi sebagai hewan coba. Pada grafik 5 akan memperlihatkan perbedaan antara pembusukan di negara 2 musim dan pembusukan di negara 4 musim yang memilliki kecepatan pembusukan yang berbeda dimana memakai babi sebagai hewan coba. ${ }^{7}$

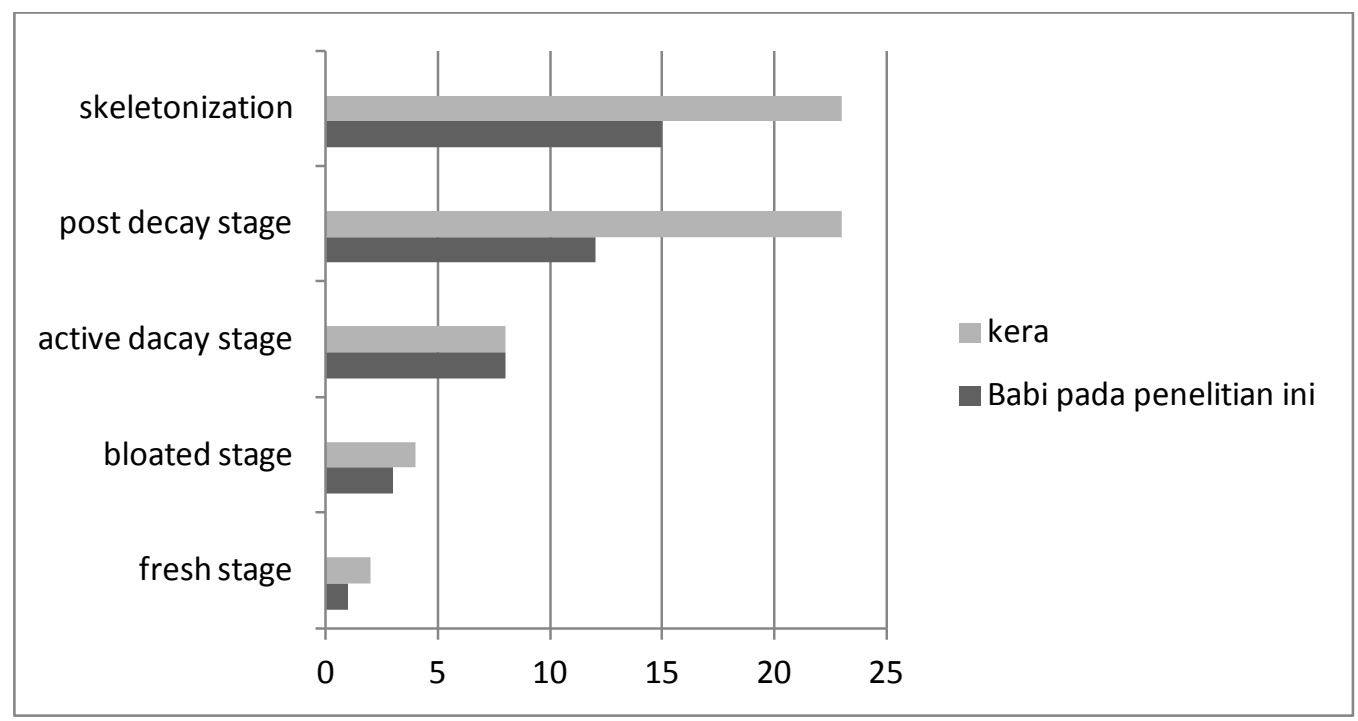

Grafik 2. Perbedaan kecepatan pembusukan pada babi dalam penelitian ini dan kera pada penelitian di malaysia. ${ }^{8}$

Dari Grafik 2. dapat dilihat perbedaan pada fresh stage dimana pada babi memakan waktu 1 hari sedangkan pada kera 2 hari, bloated stage juga terdapat perbedaan diaman pada babi memakan waktu 3 hari sedangkan pada kera memakan waktu 4 hari, active decay stage tidak terdapat perbedaan dimana babi dan kera memakan waktu 8 hari, post active decay terjadi perbedaan dimana pada babi 12 hari sedangkan pada kera memakan waktu 23 hari, sedangkan pada skeleteonization pda babi memakan 15 hari sedangkan pada kera memakan lebih dari 23 hari pada data yang diambil penelitian pada skeletonization pada kera sudah tidak di teruskan karena sudah mencapai batas penelitian. 


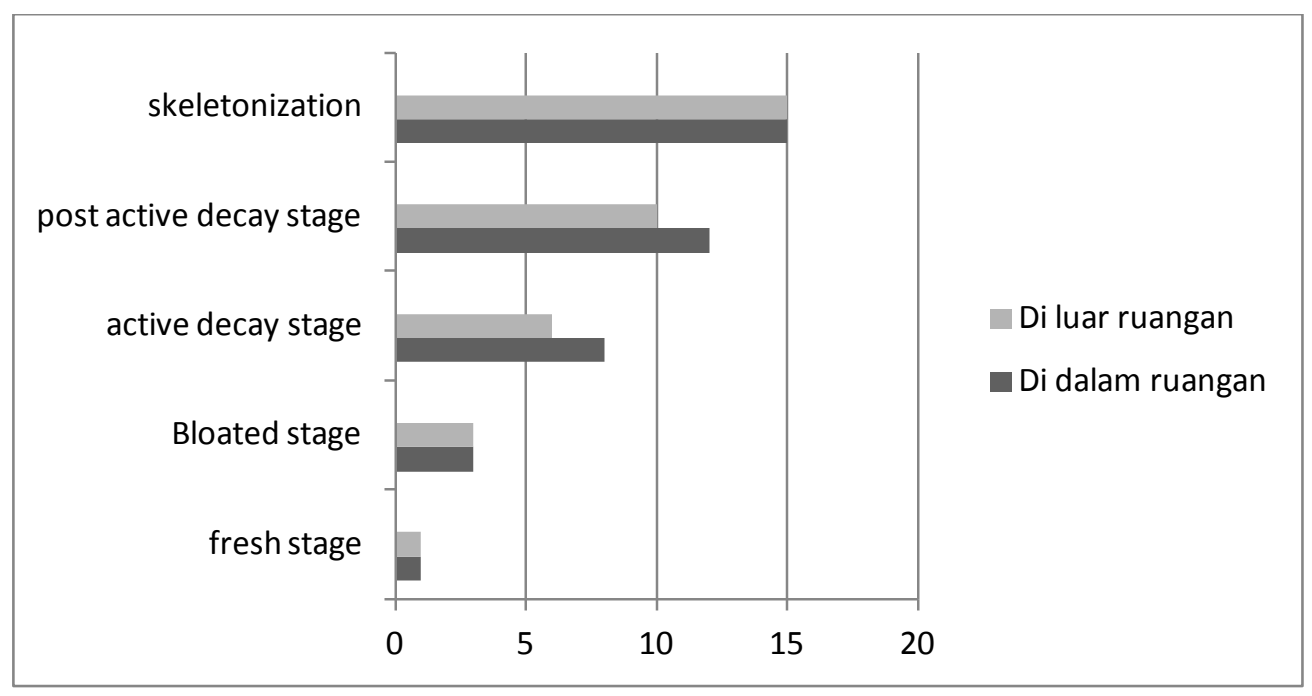

Grafik 3. Perbedaan kecepatan pembusukan di luar ruangan pada penelitian lain dan di dalam ruangan pada penelitian ini pada negara 2 musim. ${ }^{9}$

Dari grafik 3 dapat dilihat bahwa pada active decay stage terjadi perbedaan dalam proses pembusukan dimana di dalam ruangan itu prosesnya memakan waktu 4-8 hari sedangkan diluar ruangan prosesnya memakan waktu 4-6 hari. Pada post decay stage juga mengalami perbedaan dimana pembusukan di dalam ruangan memakan waktu 8-12 hari sedangkan yang diluar ruangan memakan waktu 6-10 hari.

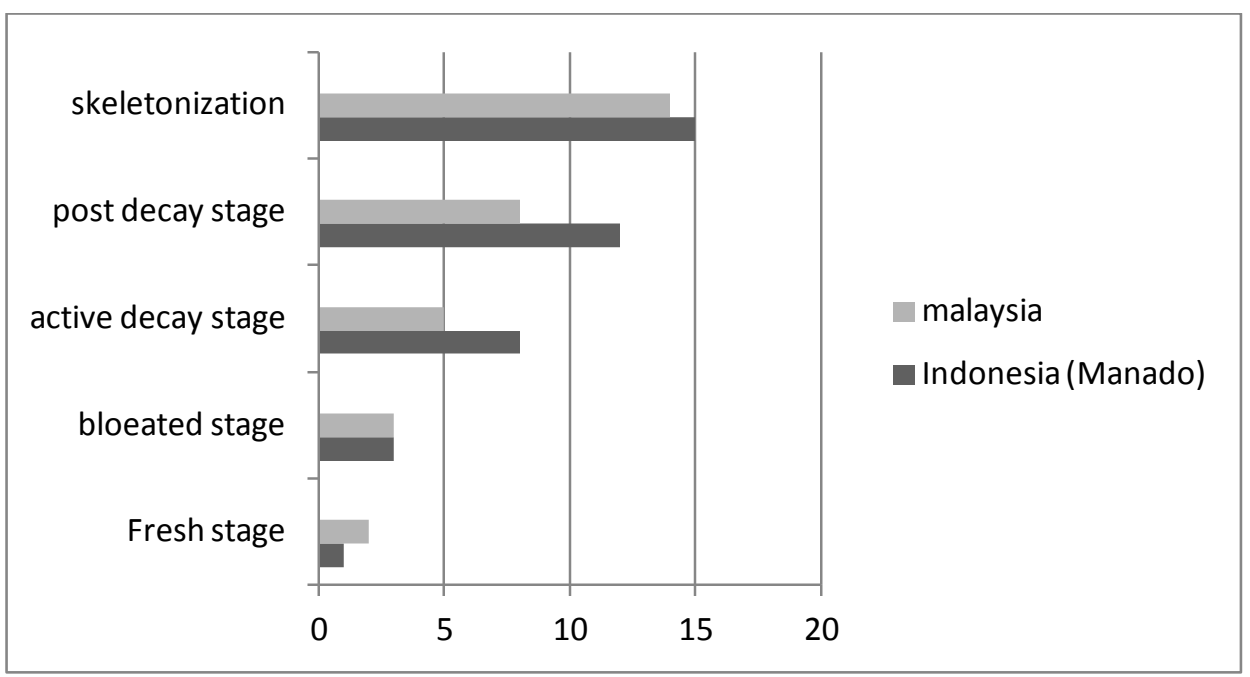

Grafik 4. Perbedaan kecepatan pembusukan di Indonesia pada penelitian ini memakai babidan Malaysia memakai babi. ${ }^{10}$

Grafik 4 menunjukkan dimana pada fresh stage sudah ada perbedaan dimana Indonesia memakan waktu 1 hari sedangkan di Malaysia memakan waktu 2 hari, pada bloated stage 
tidak ada perbedaan , active decay stage terjadi pebedaan dimana Indonesia memakan waktu 8 hari sedangkan di Malaysia memakan waktu 5 hari, post active decay juga terjadi perbedaan dimana Indonesia memakan waktu 12 hari sedangkan di Malaysia hanya 8 hari, pada skeletonization juga ada perbedaan dimana di Indonesia memakan waktu 15 hari sedangkan di Malaysia memakan waktu 14 hari.

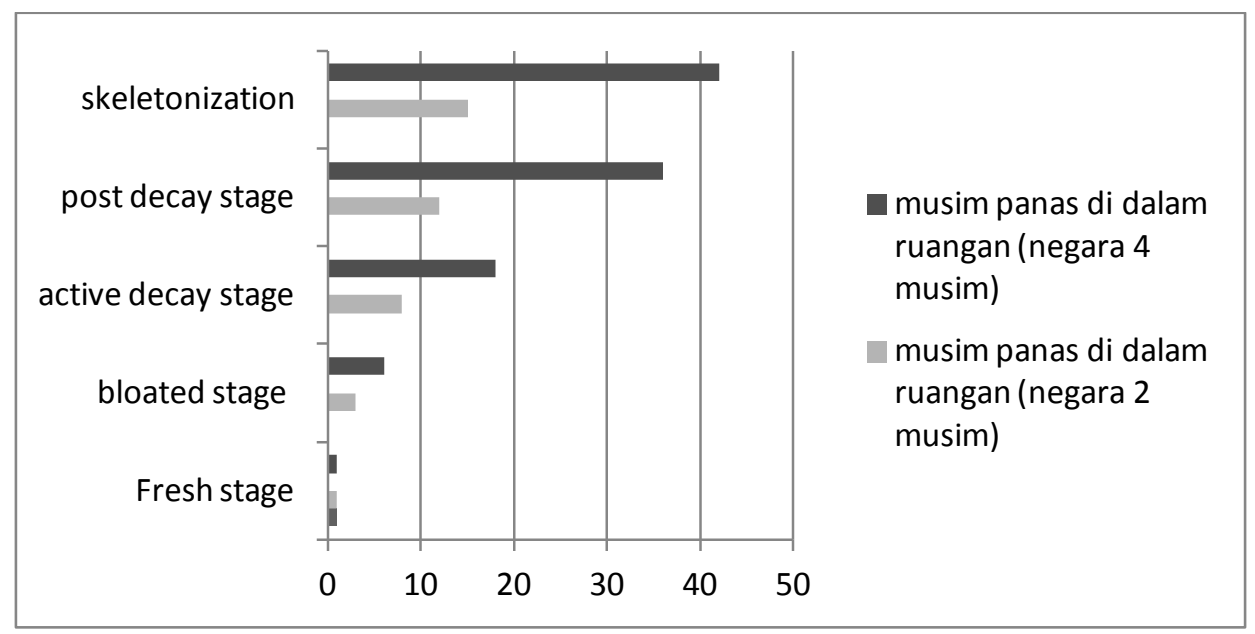

Grafik 5. Perbedaan kecepatan pembusukan di negara 2 musim pada penelitian ini dan 4 musim. ${ }^{11}$

Grafik 5 menunjukkan dimana pada bloated stage di negara 2 musim hanya memakan waktu 2-3 hari sedangkan di negara 4 musim memakan waktu 2-6 hari. Pada active decay juga menunjukkan adanya perbedaan pada proses pembusukan dimana di negara 2 musim memakan waktu 4-8 hari sedangkan di negara 4 musim memakan waktu 7-18 hari. Post decay stage juga terdapat perbedaan dalam proses terjadinya pembusukan dimana pada negara 2 musim post decay stage terjadi 8-12 hari sedangkan pada negara 4 musim post decay stage terjadi dalam waktu 17-36 hari. Pada proses terjadinya skeletonization juga terdapat perbedaan dimana pada negara 2 musim proses ini memakan waktu 6-15 hari sedangkan di negara 4 musim proses ini terjadi dalam waktu 37-42 hari.

Tahap-tahap terjadinya proses pembusukan ini terjadi juga pada manusia sehingga kita dapat mengetahui kecepatan pembusukan pada manusia melalui penelitian ini dimana kita bisa melihat dari fresh stage hingga terjadi proses skeletonization.

Tujuan dilakukannya penelitian ini bagi kehidupan manusia itu agar para dokter bisa membantu pihak yang berwenang menentukan waktu kematian dari suatu kasus ditemukannya mayat di pesisir pantai atau di tempat lainnya.

Pada manusia kita dapat menerapkan hasil penelitian ini dimana perbedaan hasil penelitian pada negara 2 musim dan 4 musim yaitu pada bloated stage 1:2, active decay stage $1: 2,25$, post active decay $1: 3$ dan pada stage skeletonization $1: 2,8 .^{10}$

\section{SIMPULAN}

Dari hasil penelitian mengenai gambaran kecepatan pembusukan di daerah pesisir pantai Manado diperoleh kesimpulan sebagai berikut : 
a) Fresh stage terjadi dalam 0-1 hari.

b) Bloated stage terjadi dalam 2-3 hari.

c) Active decay stage terjadi dalam 4-8 hari.

d) Post decay stage terjadi dalam 8-12 hari.

e) Skeletonization terjadi dalam 6-15 hari dimana kepala dan kaki yang pertama kali terjadi skeletonization.

f) Lalat yang datang menghinggapi mayat juga membantu terjadinya pembusukan dengan bertelur dan menghasilkan larva yang memakan tubuh mayat secara perlahanlahan.

g) Jadi kecepatan pembusukan di daerah pesisir pantai Manado yang berada di dalam ruangan dan di luar ruangan berbeda.

\section{SARAN}

1) Sebaiknya untuk penelitian berikutnya meningkatkan sarana prasara.

2) Mencari objek penelitian yang lebih baik.

3) Sebaiknya para dokter mempelajari kecepatan pembusukan agar dapat membantu para polisi untuk menentukan waktu kematian.

4) Penting juga untuk memperhatikan hewan-hewan pengerat dan bakteri-bakteri yang berada di dalam tubuh yang dapat membantu mempercepat terjadinya pembusukan

\section{DAFTAR PUSTAKA}

1. Dekomposisi Pasca Mati;2013 [cited 2013 okt 30] available from : http://dekomposisi_posmortem.webs.com/dekomposisi.htm

2. Budiyanto A, Widiatmaka W, Sudiono S, Sampurna B, Hertian S, Purwadianto A, et al. Ilmu kedokteran forensic kedokteran universitas Indonesia; 1997

3. Tanatologi [cited 2014 jan 22] available from : http://forensikmanado.com/home/tanatologi/

4. Penggunaan babi dalam dunia kedokteran manusia [cited 2013 okt 30] available from :http//www.respiratory.ipb.ac.

5. Bkpm. Profil kota Manado;2014 [cited 2014 jan 18] available from : http://regionalinvestment.bkpm.go.id/newsipid/id/displayprofil.php?ia=7171

6. BMKG. Perkiraan cuaca sulawesi utara;2013 [cited 2013 des 14] available from : http://.bmkg.go.id/BMKG Pusat/Meteorologi

7. Tanatologi [cited 2014 jan 22] available from : http://repository.usu.ac.id/bitstream/123456789/21606/4/Chapter II.pdf

8. Azmandi A, Abu H A. a preliminary study on the decomposition and dipteran associated with exposed carcasses in an oil palm plantation in Bandar Baharu, Kedah, Malaysia. Tropical Biomedicine 2009;26(1):1-10

9. Wangko S. Kajian gelombang suksesi serangga forensik pada bangkai hewan coba di kota Manado, Indonesia [Disertasi]. Manado: Universitas Sam Ratulangi; 2012 
10. Heo C C, Mohamad A M, Ahmad F M S, John J, Baharudin O. A preliminary study of insect succession on a pig carcass in a palm oil plantation in Malaysia. Tropical Biomedicine 2007;24(2):23-27

11. Stefano V, Emma Z, Daniele G, Anna T, Salvatore A, Cristina C. Decomposition and entomological colonization of charred bodies - a pilot study. Croat Med J. 2013;54:38793 